\title{
Phytosociology of rainfed barely along the western Mediterranean Coast, Egypt
}

\author{
Maha M. El-Midany*, Tarek M. Galal, Emad A. Farahat and Loutfy M. Hassan
}

Botany and Microbiology Department, Faculty of Science, Helwan University, Cairo, Egypt

*Corresponding author: mahaelmidany5@gmail.com

\begin{abstract}
The exponential decrease of precipitation and increase of temperature in many dry regions in the world affect negatively the growth of main crops. The presence of associated weed species with these crops may add more adverse impact on yield. The present study aims at investigating the phytosociological structure of its associated wild species with rainfed barely (Hordeum vulgare L.) at Marsa-Matrouh Governorate, Egypt. Forty-eight stands were assigned at Marsa-Matrouh city for estimating the number of associated species with rainfed barely and its visual cover. Seventy-five species belonging to 63 genera and 24 families were recorded as associated species with rainfed barley. The most dominant families were Asteraceae followed by Poaceae, Chenopodiaceae, Fabaceae, Brassicaceae. A total of 48 species were recorded as annuals. On the other hand, 25 species were perennials. Two species were biennials. Therophytes were the dominant life form. The application of TWINSPAN on the cover estimates of 75 associated species recorded in the 48 sampled stands of barley, led to recognition of eight vegetation groups.The main indicator species for vegetative groups (1, 2, 3, 4, 5, 6, 7 and 8): Glebionis coronaria, Carrichtera annua, Elymus farctus, Erucaria microcarpa and Malva parviflora are native species at the Mediterranean coastal strip. Carrichtera annua- Erucaria microcarpa group (VG 3) had the highest value of species richness. Moreover, Erucaria microcarpa-Vicia monantha (VG 6) showed the highest value of species turnover. Erucaria microcarpaVicia monantha (VG 6) showed the highest value of shannon index. Elymus farctus- Erucaria microcarpa (VG 5) showed the highest value of Simpson index. The present study will help in improving the understanding for the phytosociology of rainfed barely and will help in improving the agricultural practices to increase the yield of this plant under the prevailing harsh conditions.
\end{abstract}

Keywords: Phytosociology, rainfed barely, species richness, Marsa-Matrouh, weeds

\section{Introduction}

Barley (Hordeum vulgare L.) belongs

to the genus Hordeum in the tribe Triticeae of the grass family, Poaceae (also known as Gramineae). The Triticeae tribe is a temperate plant group containing several economically important cereals and forages as well as about 350 wild species. The genus Hordeum is unusual among the Triticeae as it contains both annual species, such as $H$. vulgare and $H$. marinum, and perennial species, such as $H$. bulbosum (Von Bothmer 1992). Barley was cultivated and used for human food, but it is now used mostly for animal feed and to produce malt; with smaller amounts used for seed and direct human consumption. Barley is used in production of starch, either for food or for the chemical industry (OECD 2004).

According to Nevo (1992) cultivated barley is growing in a zone of diverse environments, with greater concentration in temperate areas and high altitudes of the tropics and subtropics. Other than the cool highlands, barley is rarely growing in the tropics, as it is not suitable to warm humid climates. Barley requires a temperate climate; but it is also a valuable and resilient in arid and semi-arid areas of Asia, the Middle East and North Africa (FAO 2004). Barley is considered as a food crop in many parts of the world. Barley also is characterized by its good resistance to drought in comparison with other small grains crops. This feature allows it to grow near desert areas such as North Africa. In Egypt, barley is considered as a main crop, which is grown in both rainfed and favorable irrigated soils of the Nile Valley, but drought stress causes reduction of barley grain yield production, particularly in rain-fed areas (Forster et al. 2004). Barley is the main crop in 


\section{Phytosociology of rainfed barely along the western Mediterranean Coast}

the rainfed areas of the northern coastal region and in the newly reclaimed saline soil lands in Egypt. It grows on a large scale in the northwestern Mediterranean coast. Rain-fed agriculture in the Egyptian northwestern Mediterranean coast constitutes an important part of the existent economic activities. Barley production traditionally has been important in the world. The total area harvested by barley each year is around $50 \sim 80$ million ha and ranked $4^{\text {th }}$ annual cereal crop from the family of Poaceae after wheat ( 200 million ha), rice (120 150 million ha), maize (100 150 million ha) and is among the top ten crop plants in the world (around $85 \%$ of global production) (Zhou 2010). According to the Food and Agricultural organization (FAO 2017) barley production in Egypt was 115478 tons in 2017. Weeds are plants that grow where they are not wanted. They differ from other plants in being more aggressive, having specific characteristics that make them more competitive (Gomaa 2012). Crops and weeds compete in the capture and utilization of the shared resources such as light, water and nutrients (Galal \& Shehata 2015). Weed competitiveness is often linked to plant height, tiller number, growth rate, crop biomass, leaf area, and canopy ground cover (Zhao et al. 2006). Weeds have many negative impacts on agriculture including a) reduce crop yield through competition for limited resources, such as nutrients, water, and light, b) reduce crop quality: the mixture of weed seed and crop produce usually reduces their quality and market value, c) reduce crop health: act as alternate or alternative hosts for pests and diseases (Naylor 2002 \& Zimdhal 2007). Although weeds in general have negative impacts on agricultural crops, they have also benefits such as: a) control erosion in uncultivated land, b) establish a soil cover that protects the soil from hard environmental factors such as high temperature and heavy rainfall, c) serve as source of organic matter to soil, d) help to reduce leaching of mobile nutrients like nitrates through the process of nutrient recycling, e) as pasture for livestock. f) refuge for wild life and source of pesticide (Abdulraheem \& Charles 2018). Therefore, the objective of the present study is to identify the current phytosociological structure of weed/wild species communities that grow with rainfed barely at Marsa-Matrouh Governorate, Egypt.

\section{Materials and Methods Vegetation sampling}

The associated flora with rainfed barley (Hordeum vulgare L.) crop were surveyed during period (2016-2018). Forty-eight permenant stands $(10 \times 10 \mathrm{~m})$ were selected randomly to represent the cultivation of barley crop and study the vegetation associated with barley at Marsa-Matrouh Governorate. Weed assemblages, including wild and agricultural species in each stand were recorded and a list of weed species was made for each sampled stand. Visual estimation of the total cover and the cover of each weed species (\%) were assessed using Réléve method (MullerDombois \& Ellenberg 1974). Identification and nomenclature were according to Täckholm (1974) \& Boulos (1999, 2000, 2002, 2005 and 2009).

Life forms of the species were identified following the Raunkiaer scheme (Raunkiaer 1937) as follows: chamaephytes (Ch), hemicryptophytes (H), geophyteshelophytes (GH), phanerophytes (P) and therophytes (Th). The global geographical distribution (i.e. floristic regions) of the species associated with barley crop were gathered from Zohary (1966, 1972); Täckholm (1974); Boulos (1999, 2000, 2002 and 2005) \& Ahmed (2003). The global distribution was coded as follow: Mediterranean (ME), Cosmopolitan (COSM), Saharo-Arabian (SAAR), Tropical (Trop), Sudano-Zambezian (SZ), Euro-Siberian (ER-SR) and Irano-Turanian (IR-TR).

\section{Vegetation analysis}

The Two-Way Indicator Species
Analysis
(TWINSPAN), as
a classification technique, and Detrended
Correspondence Analysis (DCA), as an


ordination technique, were applied to the matrix of cover estimates of 75 species in 48 stands in barley fields. TWINSPAN is a twoway classification FORTRAN program that constructs a key to the sample classification by identifying one to several species that are particularly diagnostic of each division in the classification. The most significant feature is that the program first constructs a classification of samples, and then uses this classification to obtain a classification of species according to their ecological preferences (Hill 1979a \& Gauch and Whittaker 1981). DCA is a FORTRAN program for detrended correspondence analysis and reciprocal averaging. It was applied as a mean of axis construction to achieve a two-dimensional ordination of species and stands (Hill 1979b \& Hill and Gauch 1980).

\section{Diversity indices}

Some diversity indices were calculated for the different crops and the vegetation groups as derived from the multivariate analysis. Species richness (alpha-diversity) for each vegetation group was calculated as the average number of species per stand. Species turnover (beta-diversity) was calculated as a ratio between the total number of species recorded in a certain vegetation group and its alpha diversity (Whittaker 1972). Relative evenness or equitability (Shannon-Wiener index) of the importance value of species was expressed as $\hat{H}=-\Sigma^{s} P_{i}\left(\log P_{i}\right)$, where $S$ is the total number of species and $\mathrm{P}_{i}$ is the relative cover of the species. The relative concentration of dominance is the second group of heterogeneity indices and is expressed by Simpson's index: $\mathrm{D}=1 / \mathrm{C}\left\{\mathrm{C}=\Sigma^{\mathrm{s}}\left(\mathrm{P}_{\mathrm{i}}\right)^{2}\right\}$, where $S$ is the total number of species and $P_{i}$ is the relative cover of species. More details about these indices are available in Pielou (1975) \& Magurran (1988). It was used SDR (Species Diversity and Richness ver. 1.2) software in the calculations of different indices (PISCES Conservation Ltd).

\section{Study area and climate}

The Mediterranean coastal belt consists of a coastal plain and tableland. The coastal plain is wide with calcareous sand dunes along the coast and series of long calcareous ridges running parallel to the sea with depressions containing salt marshes. The inland tableland is a relatively flat plateau containing rich steppe habitat (Abdel Meguid et al. 2006 a, b). The main source of irrigation water in the area is rainfall. Rain distribution along the coastal zone is not even. The amount of rainfall shows steady decrease in the inland direction (FAO 1970). Marsa-Matrouh city (Matrouh Governorate) belongs to the northwestern Mediterranean coast $\left(27^{0} 38^{\backslash} \mathrm{E}\right.$ and $26^{0} 59^{\backslash} \mathrm{E}$, Fig. 1).

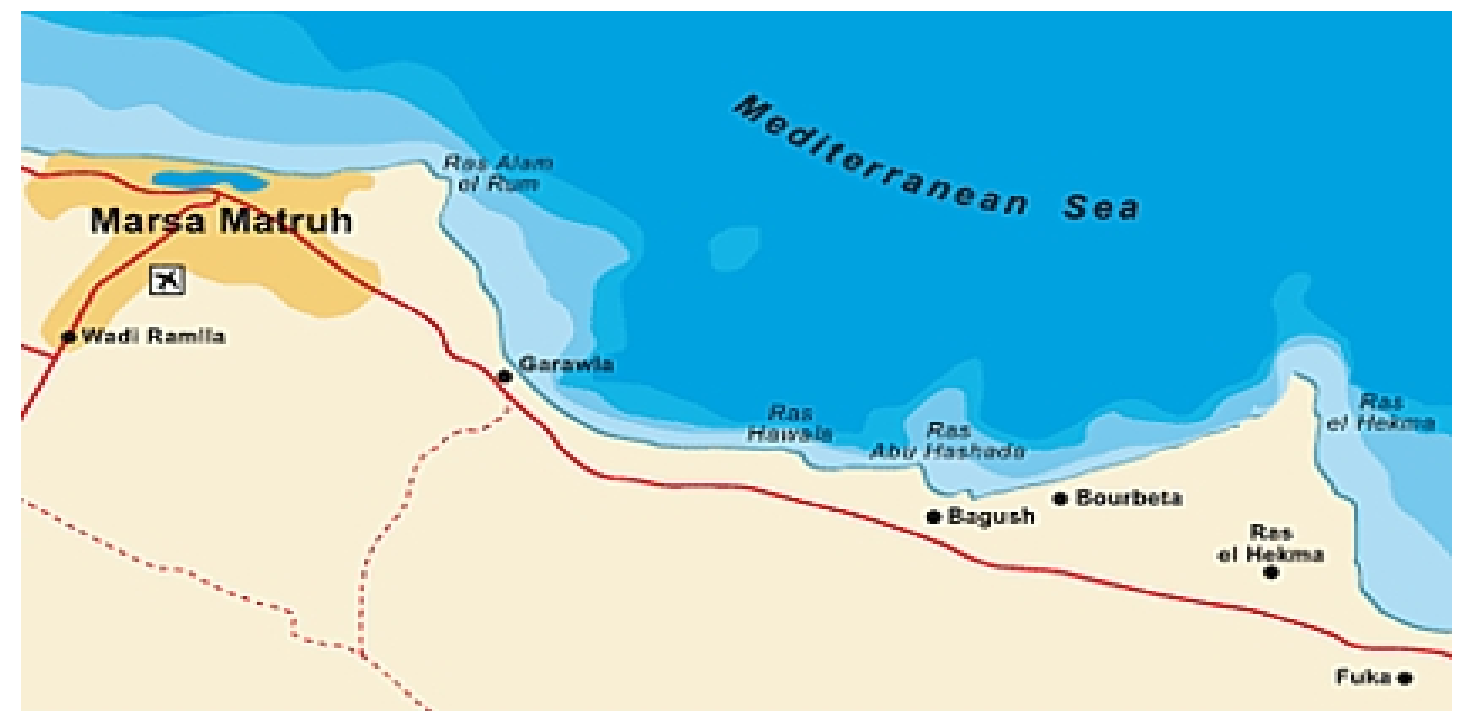

Fig. 1. Map of the Mediterranean region of Egypt indicating the study area. Source: google maps at https://www.google maps.com. 


\section{Phytosociology of rainfed barely along the western Mediterranean Coast}

The Mediterranean coastal region of Egypt lies in Meigs' "warm coastal deserts" (Meigs 1973, Fig. 2): summer warmest month with mean temperature less than $30^{\circ} \mathrm{C}$, and winter coldest month with mean temperature above $10^{\circ} \mathrm{C}$, though occasional short rainstorms occur in winter (UNESCO 1977). The Mediterranean coastal zone of Egypt months. Marsa-Matrouh climate is characterized by long hot dry summer and short cool rainy winter typical of sub-arid region, defined as "Arid Mediterranean". In general, monthly temperature varied between 14.4 and $26.8^{\circ} \mathrm{C}$, wind speed averaged at 18.9 $\mathrm{km} / \mathrm{hr}$, and the average annual rainfall ranged from 100 to $190 \mathrm{~mm}$ (DRC staff 2010). In the receives noticeable amounts of rainfall, especially in winter. The rainy period is from October to February. In summer, no or few rains are recorded, while in autumn, occasional heavy rain may occur. About $75 \%$ of the total amount of rainfalls from November to February, and only about 10\% falls during spring. December and January are the rainiest Northwestern Mediterranean coastal zone, precipitation is considered as the main source of recharge of groundwater aquifers. The main land uses in the study area are grazing and rainfed farming (or irrigated by underground and runoff water). The main annual crop is barley (Zahran \& Willis 2009).

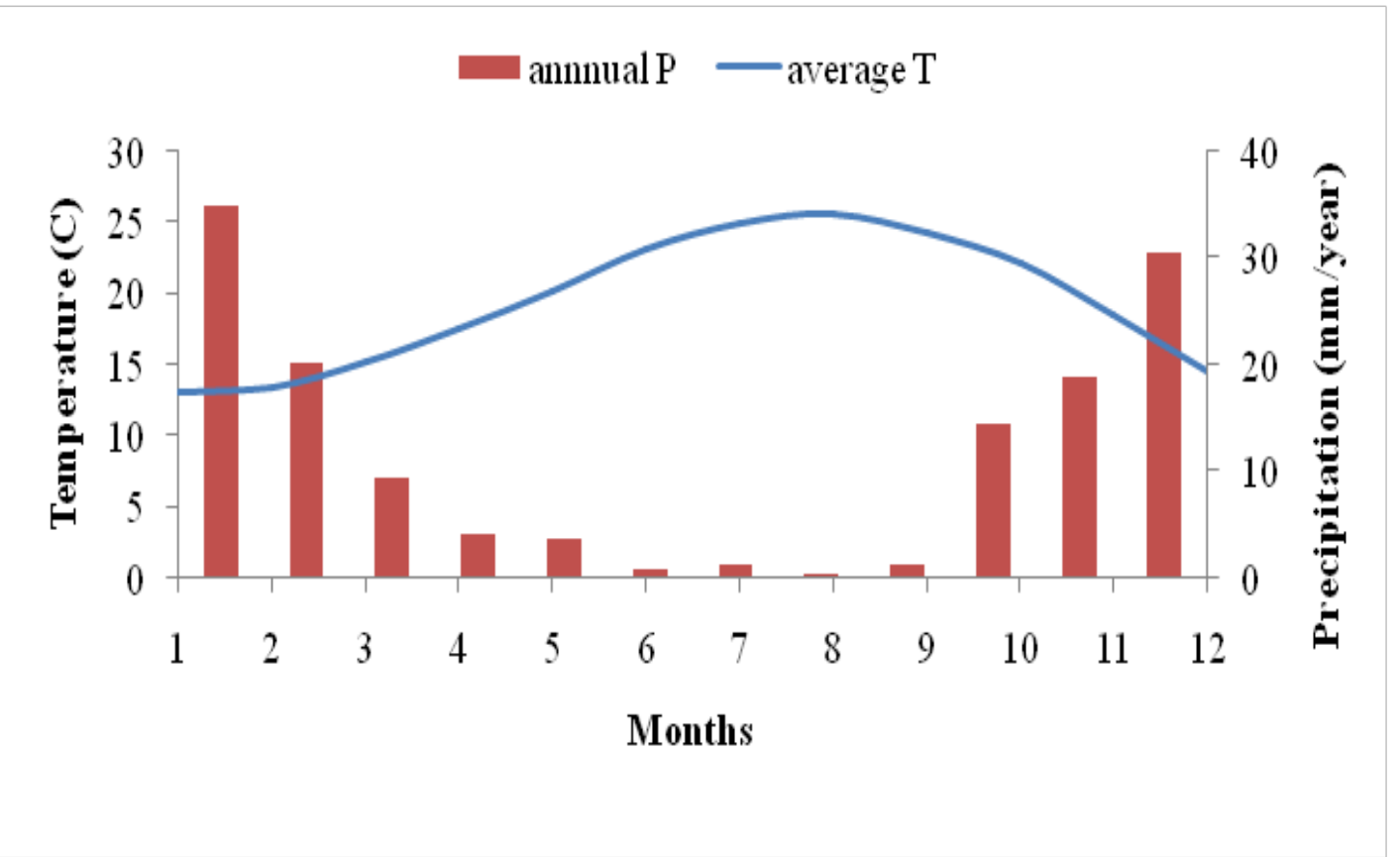

Fig. 2. Monthly average of annual precipitation and temperature of Marsa-Matrouh for the period 1901-2016.

\section{Results}

Seventy-five species belonging to 63 genera and 24 families were recorded as associated species with rainfed barley (Table 1). The most dominant families were Asteraceae represented by 17 species $(22.7 \%$ of the total number of associated species), followed by Poaceae $(9$ species $=12 \%)$, Chenopodiaceae $(8$ species $=10.7 \%)$, Fabaceae $(6$ species $=8 \%)$, Brassicaceae $(6$ species $=8 \%)$. 
Maha M. El-Midany et al.

Table 1. Genus, Species and \%Species /family for all recorded families.

\begin{tabular}{|l|c|c|c|}
\hline \multicolumn{1}{|c|}{ Species } & Genus & Species & \% Species/family \\
\hline Aizoaceae & 1 & 2 & 2.7 \\
Amaryllidaceae & 1 & 1 & 1.3 \\
Apiaceae & 1 & 1 & 1.3 \\
Araceae & 1 & 1 & 1.3 \\
Asteraceae & 15 & 17 & 22.7 \\
Boraginaceae & 2 & 2 & 2.7 \\
Brassicaceae & 6 & 6 & 8.0 \\
Chenopodiaceae & 7 & 8 & 10.7 \\
Convolvulaceae & 1 & 2 & 2.7 \\
Euphorbiaceae & 1 & 1 & 1.3 \\
Fabaceae & 5 & 6 & 8.0 \\
Fumaraceae & 1 & 1 & 1.3 \\
Geraniaceae & 2 & 3 & 4.0 \\
Lamiaceae & 2 & 2 & 2.7 \\
Liliaceae & 1 & 1 & 1.3 \\
Malvaceae & 1 & 2 & 2.7 \\
Orobanchaceae & 1 & 1 & 1.3 \\
Papaveraceae & 1 & 1 & 1.3 \\
Plantaginaceae & 1 & 3 & 4.0 \\
Poaceae & 8 & 9 & 12.0 \\
Polygonaceae & 2 & 2 & 2.7 \\
Primulaceae & 1 & 1 & 1.3 \\
Thymellaceae & 1 & 1 & 1.3 \\
Zygophyllaceae & 1 & 1 & \\
\hline
\end{tabular}

\section{Growth forms of species}

A total of 48 species were recorded as annuals such as Aegilops ventricosa, Anagallis arvensis, Avena fatua, Beta vulgaris,Cakile maritima, Emex spinosa and Medicago polymorpha. On the other hand, 25 species were perennials such as Achillea santolina,
Atriplex halimus, Convolvulus althaeoides, Cynodon dactylon, Deverra tortuosa, Echinops spinosus and launaea fragilis. Two species were biennials such as Centaurea alexandrina and Onopordum alexandrinum (Table 2).

Table 2. Floristic properties of the recorded species associated with barley.

\begin{tabular}{|c|c|c|c|}
\hline Species & Habit & Life form & Floristic category \\
\hline Aizoaceae & & & \\
\hline Mesembryanthemum crystallinum L. & Annual & Th & ME+ER-SR \\
\hline Mesembryanthemum nodiflorum L. & Annual & Th & $\mathrm{ME}+\mathrm{ER}-\mathrm{SR}+\mathrm{SA}-\mathrm{AR}$ \\
\hline Amaryllidaceae & & & \\
\hline $\begin{array}{l}\text { Narcissus tazetta subsp.raphanistrum L. } \\
\text { Apiaceae }\end{array}$ & Perennial & GH & $\mathrm{ME}$ \\
\hline $\begin{array}{l}\text { Deverra tortuosa (Desf.) DC. } \\
\text { Araceae }\end{array}$ & Perennial & Ch & SA-AR \\
\hline $\begin{array}{l}\text { Arisarum vulgare Targ. Tozz. } \\
\text { Asteraceae }\end{array}$ & Perennial & GH & ME \\
\hline Achillea santolina L. & Perennial & $\mathrm{HE}$ & ME+IR-TR \\
\hline Anthemis indurata Delile. & Annual & Th & $\mathrm{ME}+\mathrm{SA}-\mathrm{AR}$ \\
\hline Atractylis carduus(Forssk) C. Chr. & Perennial & Ch & SA-AR \\
\hline
\end{tabular}




\section{Phytosociology of rainfed barely along the western Mediterranean Coast}

Calendula arvensis L.

Carthamus glaucus M. Bieb.

Centaurea alexandrina Delile.

Centaurea calcitrapa $\mathrm{L}$.

Cichorium endivia L.

Echinops spinosus L.

Launaea fragilis (Asso) Pau.

Launaea nudicaulis(L.) Hook. F.

Matricaria recutita $\mathrm{L}$.

Onopordum alexandrinum Bioss.

Reichardia tingitana L.

Glebionis coronaria L.

Senecio glaucus subsp.coronopifolius (Maire) C. Alexander.

Sonchus oleraceus L.

\section{Boraginaceae}

Echiochilon fruticosum Desf.

Echium angustifolium Mill.

\section{Brassicaceae}

Cakile maritima Scop.

Carrichtera annua (L.) DC.

Erucaria microcarpa Bioss.

Mathiola longipetala (Vent.) DC., subsp. Livida (Delile).

Raphanus raphanistrumL.

Sisymbrium irio L.

Chenopodiaceae

Atriplex halimus L.

Atriplex semibaccata R. Br.

Bassia indica (Wieght) A. J. Scott.

Beta vulgaris L.

Cheopodium murale L.

Haloxylon salicornicum (Moq.) Bunge ex Boiss.

Salsola kali L.

Suaeda vermiculata Forssk. Ex. J. F. Gmel.

Convolvulaceae

Convolvulus althaeoidesL.

Convolvulus arvensis L.

Euphorbiaceae

Euphorbia granulata Forssk.

Fabaceae

Astragalus asterias Steven.

Scorpiurus muricatus L.

Medicago polymorpha L.

Trigonella stellata Frossk.

Vicia monantha Retz.

Vicia lutea L.

Fumaraceae

Fumaria densiflora DC.

Geraniaceae

Erodium crassifolium l' He'r.

Erodium malacoides L.

Geranium dissectum L.

\section{Lamiaceae}

Marrubium alysson L.

Salvia lanigera Poir.

Liliaceae

Asphodelus viscidulus Boiss.

Malvaceae

\begin{tabular}{|c|c|}
\hline Annual & Th \\
\hline Annual & Th \\
\hline Biennial & Th \\
\hline Annual & Th \\
\hline Annual & Th \\
\hline Perennial & $\mathrm{HE}$ \\
\hline Perennial & $\mathrm{HE}$ \\
\hline Perennial & $\mathrm{HE}$ \\
\hline Annual & Th \\
\hline Biennial & Th \\
\hline Annual & 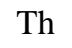 \\
\hline Annual & 111 \\
\hline Annual & Th \\
\hline Annual & Th \\
\hline Perennial & $\mathrm{Ch}$ \\
\hline Perennial & $\mathrm{Ch}$ \\
\hline Annual & Th \\
\hline Annual & Th \\
\hline Annual & 111 \\
\hline Annual & Th \\
\hline Annual & Th \\
\hline Annual & Th \\
\hline Perennial & $\mathrm{Ph}$ \\
\hline Perennial & $\mathrm{Ch}$ \\
\hline Annual & Th \\
\hline Annual & h \\
\hline Annual & Th \\
\hline Perennial & $\mathrm{Ch}$ \\
\hline Annual & Th \\
\hline Perennial & $\mathrm{Ch}$ \\
\hline Perennial & $\mathrm{HE}$ \\
\hline Perennial & $\mathrm{HE}$ \\
\hline Annual & Th \\
\hline Annual & Th \\
\hline Annual & Th \\
\hline Annual & Th \\
\hline Annual & \\
\hline Annual & Th \\
\hline Annual & Th \\
\hline Annual & Th \\
\hline Perennial & $\mathrm{HE}$ \\
\hline Annual & \\
\hline Annual & \\
\hline Annual & 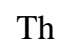 \\
\hline Perennial & $C_{\mathrm{h}}$ \\
\hline Annual & 111 \\
\hline
\end{tabular}


Maha M. El-Midany et al.

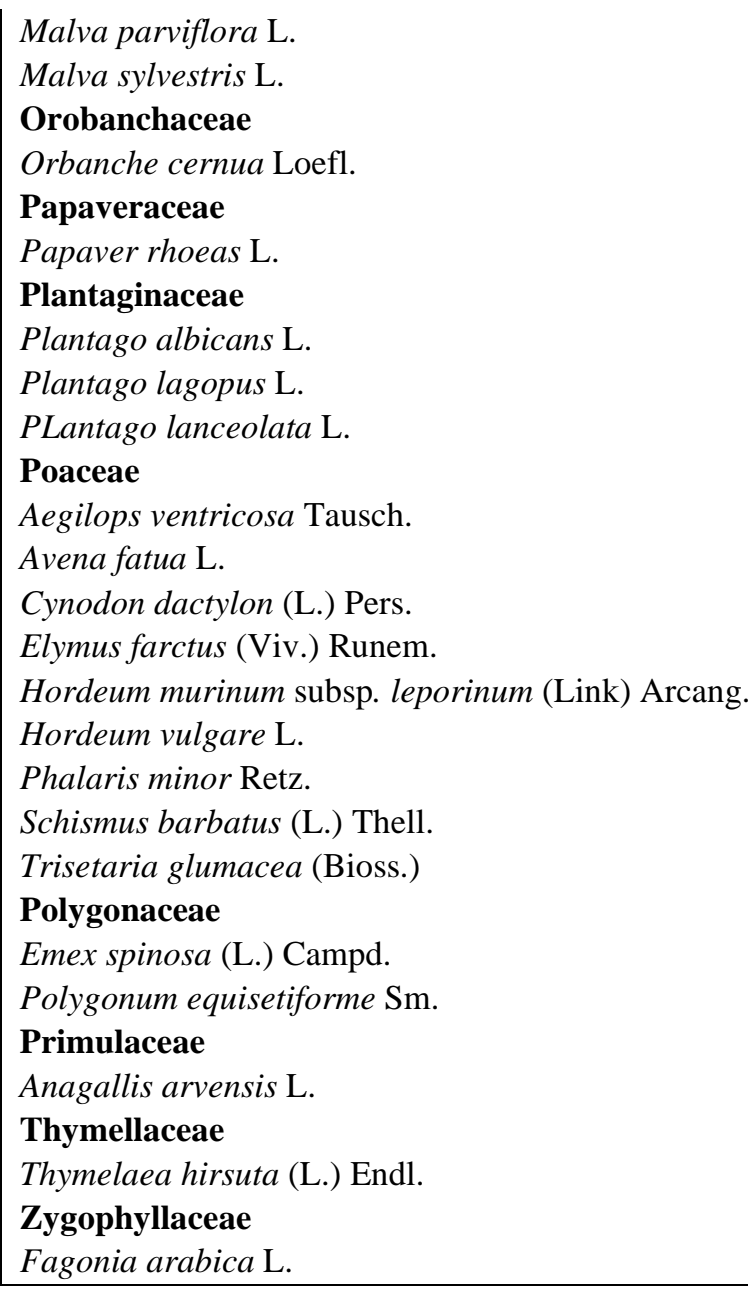

\begin{tabular}{|l|l|l|} 
Annual & Th & ME+IR-TR \\
Annual & Th & ME+ER-SR+IR-TR \\
Annual & Th & ME+SA-AR+IR-TR+S-Z \\
Annual & Th & ME \\
Perennial & HE & ME+SA-AR \\
Annual & Th & ME+IR-TR \\
Perennial & HE & ME+ SA-SI + IR-TR \\
& & ME \\
Annual & Th & COSM \\
Annual & Th & COSM \\
Perennial & GH & ME \\
Perennial & GH & ME+IR-TR \\
Annual & Th & ME+IR-TR \\
Annual & Th & ME+IR-TR \\
Annual & Th & ME+SA-AR+IR-TR \\
Annual & Th & ME \\
Annual & Th & \\
Annual & Th & ME+SA-AR \\
Perennial & GH & ME+IR-TR \\
Annual & Th & ME+ER-SR+IR-TR \\
Perennial & Ch & ME+SA-AR \\
Perennial & Ch & ER-SR \\
\hline
\end{tabular}

\section{Life forms}

The life form spectra of the recorded species associated with rainfed barley indicated the presence of five life form categories: hemicryptophytes, geophytes, chamaephytes, therophytes and phanerophytes (Fig. 3). Therophytes were the dominant life

form represented by 50 species (66.7\% of the total number of chaemophytes species), followed by chaemophytes $(11$ species = $14.7 \%)$, hemicryptophytes $(8$ species $=$ $10.7 \%$ ), geophytes ( 5 species $=6.7 \%$ ) and phanerophytes $(1$ species $=1.3 \%)$.

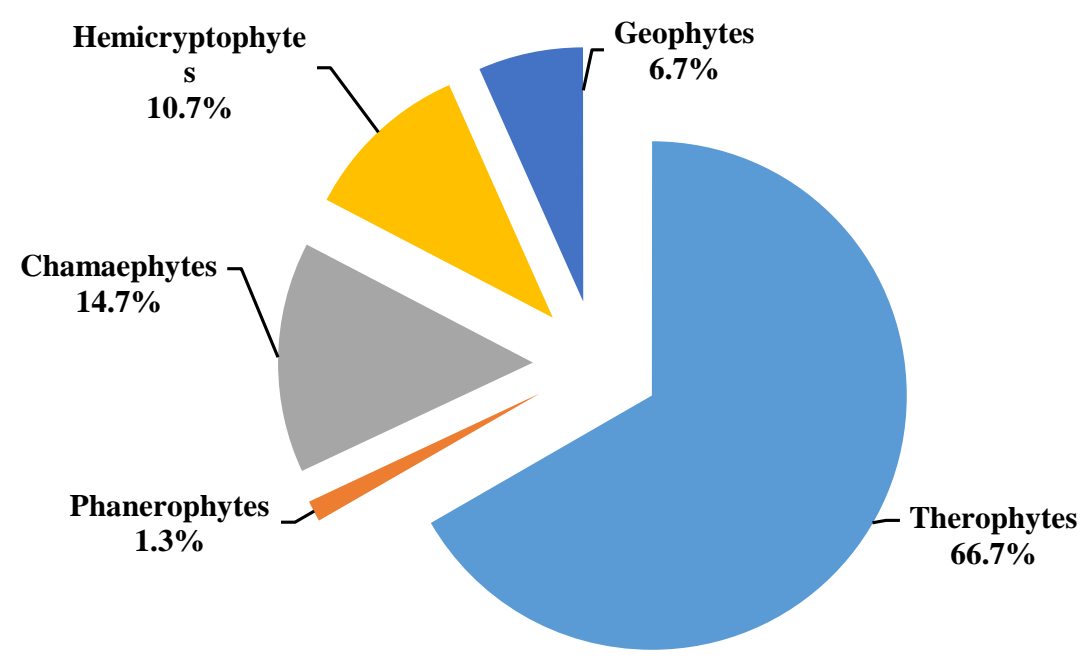

Fig. 3. Life form spectra of the recorded associated wild species with rainfed barley at Marsa-Matrouh. 


\section{Phytosociology of rainfed barely along the western Mediterranean Coast}

\section{Chorological analysis}

The spectrum of the global distribution of the recorded species associated with barley indicated that bi-regional taxa were the dominant elements, represented by $42.7 \%$

species, and followed by mono-regional elements (29.3\% species), pluri-regional (18.7\% species) and cosmopolitans (9.3\% species) (Fig. 4).

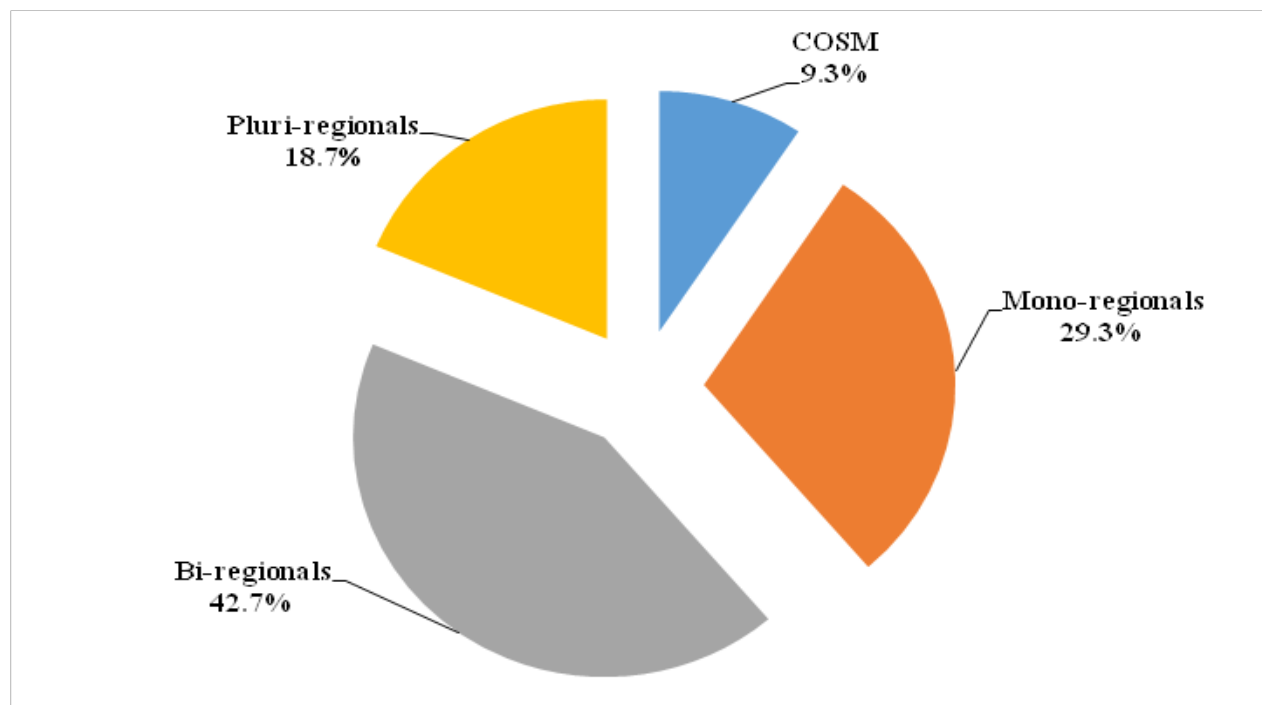

Fig. 4. Floristic category of the recorded wild species associated with rainfed barley at Marsa-Matrouh.

\section{Vegetation analysis}

The application of TWINSPAN (Fig. 5) on the cover estimates of 75 associated species recorded in the 48 sampled stands of barley, led to recognition of eight vegetation groups. These groups showed a reasonable segregation along the ordination plane axes 1 and 2 of DECORANA (Fig. 6). The vegetation groups were named after the first dominant species associated with rainfed barley (the species that have the highest presence percentage and / or the highest cover). The presence of barley was $100 \%$ in all vegetation groups, while cover varied from one group to another. The description of these vegetation groups was indicated as follows:

\section{Glebionis coronaria- Onopordum} alexandrinum (VG 1): It includes six stands and ten species. In this group the cover of barley was $26.7 \%$, while the cover of Glebionis coronaria was $9.7 \%$ and the cover of Onopordum alexandrinum was $1.5 \%$. The associated species include Matthiola longipetala, Mesembryanthemum nodiflorum and Atractylis carduus.
Glebionis coronaria- Carrichtera annua (VG 2): It includes ten stands and 30 species. In this group, the cover of barley was 33\%, while the cover of Glebionis coronaria was $4.6 \%$ and the cover of Carrichtera annua was $3.1 \%$. The associated species include Erucaria microcarpa, Plantago lanceolata and Schismus barbatus.

Carrichtera annua- Erucaria microcarpa (VG 3): It includes. Four stands and 13 species. In this group, the cover of barley was $60 \%$, while the cover of Carrichtera annua was $7.2 \%$ and the cover of Erucaria microcarpa was $1 \%$. The associated species include Launaea fragilis, Onopordum alexandrinum and Trigonella stellata.

Elymus farctus- Trigonella stellata (VG 4): It includes one stands and 14 species. In this group, the cover of barley was $60 \%$, while the cover of Elymus farctus was represented by $10 \%$ and the cover of Trigonella stellata was $1.5 \%$. The associated species include Carrichtera annua, Carthamus glaucus and Scorpiurus muricatus. 
Maha M. El-Midany et al.

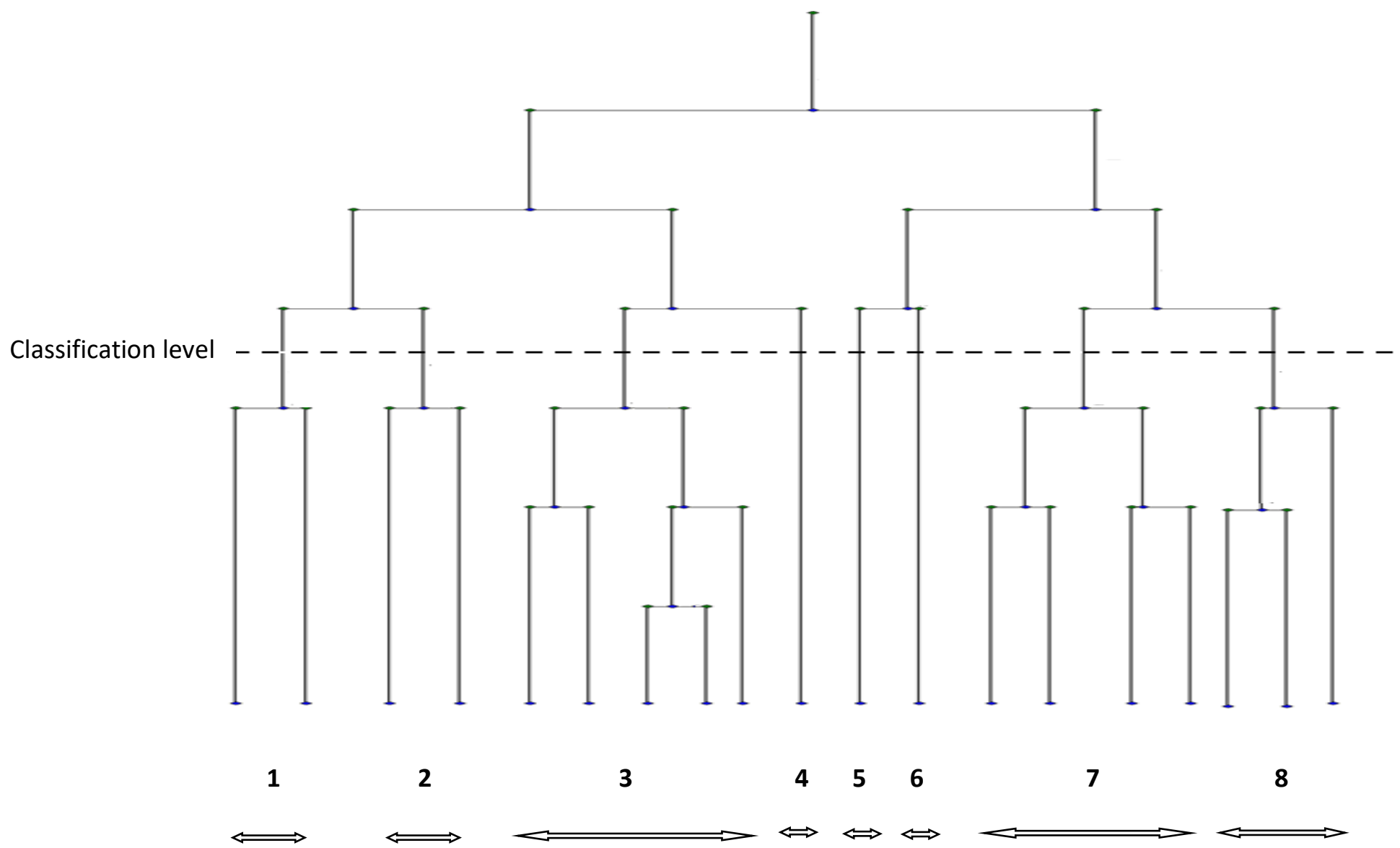

Fig. 5. The dendrogram resulting from the application of TWINSPAN on the 48 sampled stands: (1) Glebionis coronaria- Onopordum alexandrinum (2) Glebionis coronaria- Carrichtera annua (3) Carrichtera annua- Erucaria microcarpa (4) Elymus farctus- Trigonella stellata (5) Elymus farctus- Erucaria microcarpa (6) Erucaria microcarpa-Vicia monantha (7) Erucaria microcarpa- Glebionis coronaria (8) Malva parviflora- Chenopodim murale. 


\section{Phytosociology of rainfed barely along the western Mediterranean Coast}

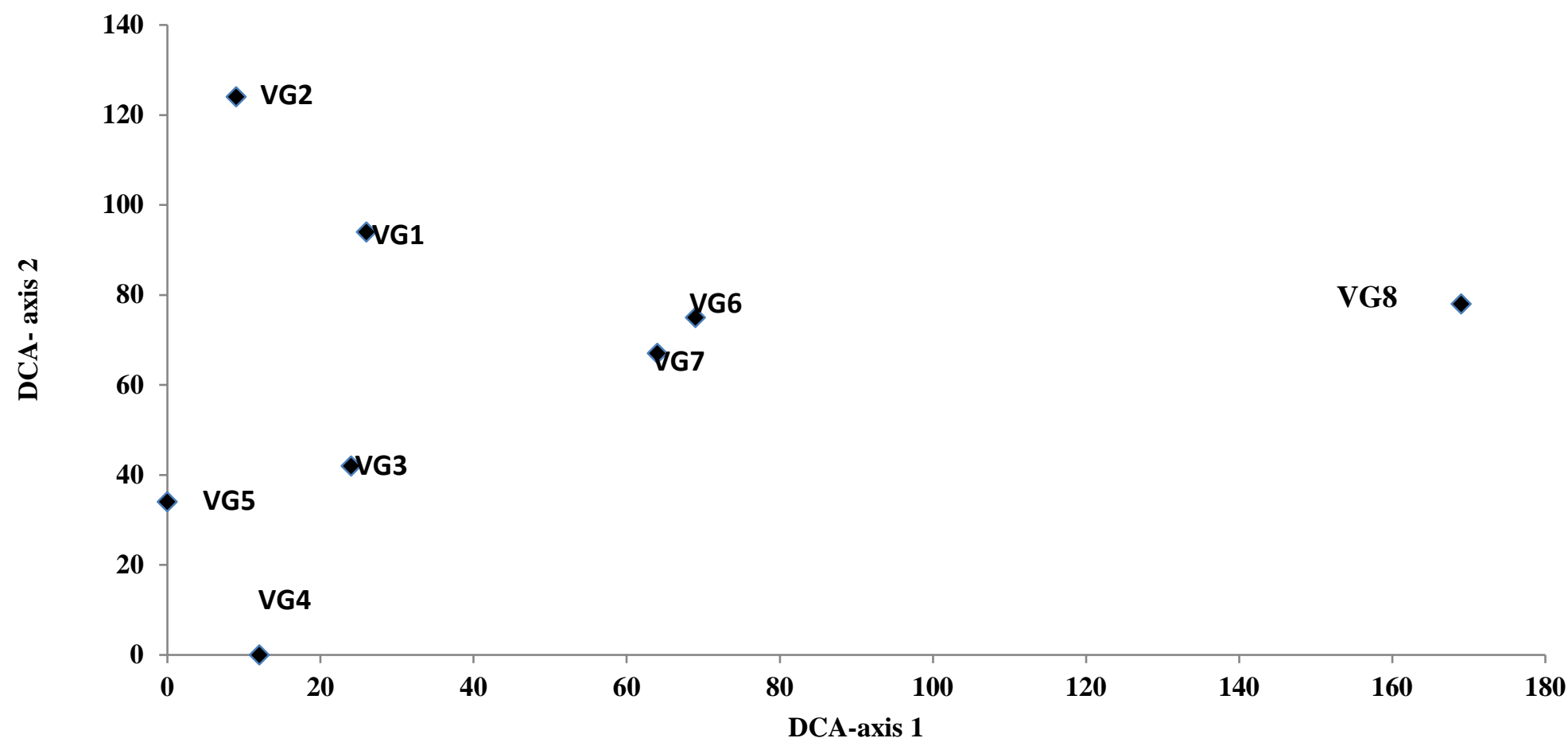

Fig. 6. DCA ordination of the eight vegetation groups identified after the application of TWINSPAN on the 48 sampled stands: (1) Glebionis coronariaOnopordum alexandrinum (2) Glebionis coronaria-Carrichtera annua (3) Carrichtera annua- Erucaria microcarpa (4) Elymus farctus- Trigonella stellata (5) Elymus farctus- Erucaria microcarpa (6) Erucaria microcarpa-Vicia monantha (7) Erucaria microcarpa- Glebionis coronaria (8) Malva parvifloraChenopodim murale. 
Elymus farctus- Erucaria microcarpa (VG 5): It includes 4 stands and 29 species. In this group, the cover of barley was $20 \%$, while the cover of Elymus farctus was $3.1 \%$ and the cover of Erucaria microcarpa was $1.7 \%$. The associated species include Convolvulus althaeoides, Scorpiurus muricatus and Trigonella stellata.

Erucaria microcarpa- Vicia monantha (VG 6): It includes 11 stands and 49 species. In this group, the cover of barley was $36.4 \%$, while the cover of Erucaria microcarpa was1.5\% and the cover of Vicia monantha was1.5\%. The associated species include, Vicia lutea, Carrichtera annua and Emex spinosa.

Erucaria microcarpa- Glebionis coronaria (VG 7): It includes six stands and 23 species. In this group, the cover of barley was $37.5 \%$, while the cover of Erucaria microcarpa was $6.5 \%$ and the cover of Glebionis coronaria was $5.8 \%$. The associated species include Achillea santolina, Convolvulus arvensis and Thymelaea hirsuta.

Malva parviflora- Chenopodim murale (VG 8): It includes six stands and 28 species. In this group, the cover of barley was $30.8 \%$, while the cover of Malva parviflora was $9.8 \%$ and the cover of Chenopodim murale was $9.4 \%$. The associated species include Achillea santolina, Atriplex semibaccata and Mesembryanthemum nodiflorum.

\section{Species diversity}

The total number of associated species with barley varied from 49 species in Erucaria microcarpa-Vicia monantha group (VG 6) to 10 species in group Glebionis coronariaOnopordum alexandrinum (VG 1) (Table 3). Carrichtera annua- Erucaria microcarpa group (VG 3) had the highest value of species richness (23.1 species/ stand), while Elymus farctus- Erucaria microcarpa group (VG 5) had the lowest value of species richness (2.0 species/ stand). Moreover, Erucaria microcarpa- Vicia monantha (VG 6) showed the highest value of species turnover (16.3), while Carrichtera annua- Erucaria microcarpa (VG 3) showed the lowest value of species turnover (0.6). Erucaria microcarpaVicia monantha (VG 6) showed the highest value of Shannon index (2.9), while Carrichtera annua- Erucaria microcarpa (VG 3) showed the lowest value of Shannon index (1.0). Elymus farctus- Erucaria microcarpa (VG 5) showed the highest value of Simpson index (6.3), while Carrichtera annuaErucaria microcarpa (VG 3) showed the lowest value of Simpson index (1.7).

Table 3. Diversity indices of the 8 vegetation groups produced from TWINSPAN. Maximum and minimum values are underlined.

\begin{tabular}{|l|c|l|l|c|c|c|c|c|}
\hline $\mathbf{v G}$ & $\begin{array}{c}\text { No. of } \\
\text { stands }\end{array}$ & $\mathbf{1}^{\text {st }}$ dominant species & $\mathbf{2}^{\text {nd }}$ dominant species & $\begin{array}{c}\text { No. of } \\
\text { species }\end{array}$ & $\begin{array}{c}\text { Species } \\
\text { richness }\end{array}$ & $\begin{array}{c}\text { Species } \\
\text { turnover }\end{array}$ & $\begin{array}{c}\text { Shannon } \\
\text { index }\end{array}$ & $\begin{array}{c}\text { Simpson } \\
\text { index }\end{array}$ \\
\hline $\mathbf{1}$ & 6 & Glebionis coronaria & Onopordum alexandrinum & $\underline{10}$ & 10.2 & 1.0 & 1.4 & 2.6 \\
$\mathbf{2}$ & 10 & Glebionis coronaria & Carrichetra annua & 30 & 4.2 & 7.1 & 2.4 & 4.6 \\
$\mathbf{3}$ & 4 & Carrichetra annua & Erucaria microcarpa & 13 & $\underline{23.1}$ & $\underline{0.6}$ & $\underline{1.0}$ & $\underline{1.7}$ \\
$\mathbf{4}$ & 1 & Elymus farctus & Trigonella stellata & 14 & 6.0 & 2.3 & 1.2 & 1.9 \\
$\mathbf{5}$ & 4 & Elymus farctus & Erucaria microcarpa & 28 & $\underline{2.0}$ & 14.0 & 2.6 & $\underline{6.3}$ \\
$\mathbf{6}$ & 11 & Erucaria microcarpa & Vicia monantha & $\underline{49}$ & 3.0 & $\underline{16}$ & $\underline{2.3}$ \\
$\mathbf{7}$ & 6 & Erucaria microcarpa & Glebionis coronaria & 23 & 4.8 & 4.8 & 2.1 & 5.8 \\
$\mathbf{8}$ & 6 & Malva parviflora & Cheopodium murale & 28 & 4.0 & 7.0 & 2.4 \\
\hline
\end{tabular}

\section{Plant and soil analysis}

The collected soil from barley fields at MarsaMatrouh was characterized by high contents of sand $(71 \%)$ and low alkalinity ( $\mathrm{pH}=7.98)$. The soil had poor nutrient contents for all the analysed elements (Table 4). The correlation analysis showed that some soil variables had significant positive correlations with plant inorganic elements such as soil Zn with plant $\mathrm{Zn}$, soil K with plant K, soil Mn with plant Mn 


\section{Phytosociology of rainfed barely along the western Mediterranean Coast}

and soil Na with plant Na. On the other hand, some other soil variables had significant negative correlations with plant inorganic elements such as soil $\mathrm{P}$ with plant $\mathrm{P}$, soil Fe with plant $\mathrm{Fe}$ and soil $\mathrm{Mg}$ with plant $\mathrm{Mg}$ (Table 5).

Table 4. The soil characteristics (Mean \pm SD) of rainfed barely fields at Marsa-Matrouh Governorate.

\begin{tabular}{|lc|}
\hline Mechanical analysis \% & \\
Gravels & $2.58 \pm 1.78$ \\
Coarse sand & $17.58 \pm 16.00$ \\
Fine sand & $53.48 \pm 15.50$ \\
Silt & $21.48 \pm 6.83$ \\
Clay & $2.55 \pm 0.72$ \\
Chemical analysis & \\
pH & $7.98 \pm 0,78$ \\
EC dS/m & $0.78 \pm 1.16$ \\
mg kg ${ }^{-1}$ & \\
P & $6.04 \pm 0.36$ \\
$\mathrm{Mg}$ & $6.44 \pm 2.24$ \\
$\mathrm{~K}$ & $3.80 \pm 1.75$ \\
$\mathrm{Na}$ & $1.23 \pm 1.51$ \\
$\mathrm{Zn}$ & $0.33 \pm 0.26$ \\
$\mathrm{Fe}$ & $8.34 \pm 3.91$ \\
$\mathrm{Mn}$ & $0.21 \pm 0.14$ \\
meq/l & \\
$\mathrm{HCO}$ & \\
\hline
\end{tabular}

Table 5. Simple linear correlation (r) between soil variables and nutrients of Hordeum vulgare in rainfed fieldsat Marsa-Matrouh Governorate.

\begin{tabular}{|l|ccccccc|}
\hline & P_Soil & Zn_Soil & Fe_Soil & K_Soil & Mg_Soil & Mn_Soil & Na_Soil \\
\hline P_plant & -0.31 & 0.47 & 0.25 & 0.22 & $-\mathbf{0 . 8 2}$ & $\mathbf{- 0 . 8 7}$ & 0.34 \\
K_plant & $\mathbf{0 . 9 1}$ & $\mathbf{0 . 9 3}$ & $\mathbf{0 . 9 9}$ & $\mathbf{0 . 9 9}$ & 0.48 & 0.40 & $\mathbf{0 . 9 7}$ \\
Mg_plant & -0.62 & 0.14 & -0.10 & -0.13 & $-\mathbf{0 . 9 7}$ & $\mathbf{- 0 . 9 9}$ & 0.00 \\
Na_plant & 0.19 & $\mathbf{0 . 8 4}$ & $\mathbf{0 . 6 8}$ & $\mathbf{0 . 6 6}$ & -0.45 & -0.53 & $\mathbf{0 . 7 5}$ \\
Fe_plant & $\mathbf{- 0 . 8 9}$ & -0.29 & -0.52 & -0.54 & $\mathbf{- 0 . 9 8}$ & $\mathbf{- 0 . 9 6}$ & -0.43 \\
Mn_plant & 1.00 & $\mathbf{0 . 7 1}$ & $\mathbf{0 . 8 6}$ & $\mathbf{0 . 8 8}$ & $\mathbf{0 . 7 8}$ & $\mathbf{0 . 7 2}$ & $\mathbf{0 . 8 1}$ \\
Zn_plant & $\mathbf{0 . 9 6}$ & $\mathbf{0 . 8 6}$ & $\mathbf{0 . 9 6}$ & $\mathbf{0 . 9 6}$ & $\mathbf{0 . 6 1}$ & 0.53 & $\mathbf{0 . 9 2}$ \\
\hline
\end{tabular}

\section{Discussion}

Zahran \& Willis (1992) reported that the Western Mediterranean coastal belt is the richest part of Egypt in its floristic composition, which is attributed to its relatively high rainfall. Human disturbance such as cultivation, clearing of vegetation and grazing are common in the Western Mediterranean region (Heneidy\& Bidak
1998). In this study 75 species belonging to 24 families were recorded. Annual species (48 species) were highly represented in the present study, which may be attributed to their short life cycle that enables them to resist the instability of the agroecosystem (Sans \& Msalles 1995). Also, they are generally characterized by high allocation of resources to 
the reproductive organs and the production of flowers early in their life span to ensure some seed production of flowers early even in a year when he growing season is cut short (Sans \& Masalles 1995). Most perennial species are not adapted to successful establishment in arable crops (Marshall 1989). Asteraceae had the highest contribution, and this was agreed with (Shaltout et al. 2015) and its contribution to Egyptian flora. Mediterranean elements were the most represented, followed by IranoTuranian, but Sudano- Zambezian elements were the least and this was agreed with that reported by Kosinová (1972) and Shaltout et al. 2015. In the present study, a mixture of different floristic elements such as Cosmopolitan, Pantropical, Palaeotropical, Neotropical, Saharo-Arabian, SudanoZambezian, Irano-Turanian and Euro-Siberian elements were represented by different numbers of species. This can be attributed to human impact, agriculture and capability of floristic elements to penetrate the study area from several adjacent phytogeographical regions (Shaltout et al. 2015).

The life form provides information, which may help in assessing the response of vegetation to the variations in the environmental factors (Galal 2005). The Mediterranean climate was designated as a "theropyhte climate" because of high percentage of this life form in several Mediterranean floras (Raven 1971). The present study indicated the predominance of therophytes (66.7\%) over other life forms. This dominance is a response to the hot-dry climate, topographic variation and biotic influence, in addition to the adverse climatic conditions, moisture deficiency and substrate instability probably. (Heneidy and Bidak 2001; Shehta and Galal 2014 \& Shaltout et al. 2015). According to Galal (2001) \& Khalafallah et al. (2016 a), therophytes are the main life forms in weed studies and most of them are characteristic to the cultivated lands in the Egyptian flora.

The high species richness may be related to this environmental heterogeneity that promotes diversity (Palmer \& Maurer 1997). The variation in species richness, diversity and evenness among the different community types may be attributed to differences in soil characteristics, substrate discontinuities and the allelopathic effects of one or more invasive species depending on their relative dominance among other associated species, in addition to habitat characteristics (Galal and shehata, 2015; Khalafallah et al. 2016 a). Moreover, the difference in field management practices may also explain the differences in species richness (Gomaa 2012). Phytosocioloists used ordination techniques to simplify distribution patterns along the gradients of environmental variables (Spink 1992). The main indicator species for vegetative groups $(1,2,3,4,5,6,7$ and 8): G. coronaria, C. annua, E. farctus, E. microcarpa and $M$. parviflora are native species at the Mediterranean coastal strip. Mediterranean desert of Egypt varies along two gradients of habitat factors: moisture, availability and physiographic heterogeneity (Shaltout 1985). The vegetation groups resulted from TWINSPAN classification are clearly distinguished by the first two DCA axes. In total, these groups reflect the dominance of the indicator species in barely fields according to the degree of agriculture practices, plant density and/or collection of rain water at land depressions (Personal observations).These results agree with results of Gomma (2012) and Khalafallah et al. (2016b), who noted that that season, soil characteristics, management practices and plant density affected on the composition of plant community. There are few studies carried out on the weed assemblage in rainfed barely during the last 50 years, which can be summarized as follow:

I-Tadros and Atta (1958) recorded Achillea satolina as the main associated species in the barley fields at Marsa Matrouh and Burg El Arab area; with sub-association of Arisarum vulgare and with 49 associated species.

II-El Hadidi and Ayyad (1975) recorded 40 species in Wadi Habas (Marsa-Matrouh). Convolvolus altheoides and Plantago albicans were co-dominanted in the study area, while $A$. santolina was common and $A$. vulgare was rare. The fallow areas between barley cultivation are co-dominated by Trigonella maritima and Lolium rigidum.

III- Kosniva (1975) described the main weed communities of rainfed barley in the Mediterranean coastal area. She recorded the 


\section{Phytosociology of rainfed barely along the western Mediterranean Coast}

presence of the alliance of $A$. santolina with 45 associated species. The cultivated plots were surrounded by vast areas of uncultivated semidesert (represent winter aspect of private Bedouins in Burg El Arab area).

IV-Hassan and El-Bakry (2003) recorded 76 species associated with rainfed barley. Devera tortuosa, A. vulgare, A. santolina and Calendula arvensis were recorded as the indicator species. Asphodelus microcarpus, A. vulgare, Plantago albicans, Trigonella maritima, Launaea mucronata, Anagallis arvensis, Emex spinosa, Malva silvestris and Vicia lutea were recorded as dominant species. Comparing with the present study, 75 species belonging to 63 genera were recorded as associated species with rainfed barley, $G$. coronaria, C. annua, E. farctus, E. microcarpa and $M$. parviflora were recorded as the indicator species. G. coronaria, Carrichtera annua and E. microcarpa were recorded as the most common dominant species. In conclusion, the presence of native wild species and other agricultural weeds with rain-fed barely could have adverse effects on the vegetative biomass and grain yield. The interaction between these species and barely in terms of competition, allelopathy.etc, should be studied and taken into consideration during the cultivation of rainfed barely.

\section{References}

Abdel-Meguid, M.; Abdou, M.; Hany, M.A. and Dietrich, J. 2006b. A remote sensing approach for detecting land use/land cover on the coastal project management area of Marsa Matrouh. ${ }^{\text {rd }}$ Arab Water Regional Conference. Research Advancement in Managing Limited Water Resources. Cairo, Egypt.

Abdel-Meguid, M.; Abed, L.; Dietrich, J. and Maha, M.A. 2006a. Water availability and vegetations along the coastal dune area in Marsa Matrouh. $3^{\text {rd }}$ Arab Water Regional Conference.Research Advancement in Managing Limited Water Resources. Cairo, Egypt.

Abdulraheem, M.I and Charles, E.F. 2018. Characteristics Effects of Weed on Growth Performance and Yield of Maize (Zea Mays). Biomedical Journal of Scientific and Technical Research. 7:3.
Ahmed, D. A. 2003. Current status of the flora and vegetation of Nile Delta Region. M.Sc. Thesis, Faculty of Science. Tanta University, Tanta.321 pp.

Boulos, L. 1999. Flora of Egypt. Vol. I (Azollaceae - Oxalidaceae). Al Hadara Publishing, Cairo, Egypt. 419 pp.

Boulos, L. 2000. Flora of Egypt. Vol. II (Geraniaceae - Boraginaceae). Al Hadara Publishing, Cairo, Egypt. 352 pp.

Boulos, L. 2002. Flora of Egypt. Vol. III (Verbinaceae - Compositae). Al Hadara Publishing, Cairo, Egypt. 373 pp.

Boulos, L. 2005. Flora of Egypt. Vol. IV. Monocotyledons

(AlismataceaeOrchidaceae). Al Hadara Publishing, Cairo, Egypt. 617 pp.

Boulos, L. 2009. Flora of Egypt Checklist, Revised Annotated Edition. Al Hadara Publishing, Cairo, Egypt.

DRC Staff. 2007-2015. Integrated Agriculture Development of Northwestern coastal wadies. Annual report. Desert Research Center publications.

El-Hadidi, M.N. and Ayyad, M.A. 1975. Floristic and ecological features of Wadi Habis (Egypt). Colloquesinternationaux du CNRS, No.235 - La flore du Méditerranéen: Essai de systématiquesynthétique.

FAO. 1970. Pre-investment Survey on the Northwestern Coastal Zone, Physical Conditions and Water Resources. United Nations Development Programme.

FAO. 2004. Akar, T.; Avci, M. and Dusunceli, F. BARLEY: Post-Harvest Operations Organisation: The Central Research Institute for Field Crops, P.O. Box. 226, Ulus, Ankara,Turkey.

FAO. 2017. Internal report, available at: https://knoema.com/atlas /Egypt/topics /Agriculture/Crops-Production-Quantitytonnes/Barley-production.

Forster, P.; Ellis, R.; Moir, J.; Talamè, V.; Sanguineti, M.C.; Tuberosa, R.; This, D.; Teulat-Merah, B.; Ahmed, I.; Mariy, S.A.E.E.; Bahri, H.; El Ouahabi, M.; Zoumarou-Wallis, N.; El-Fellah, M. and Ben Salem, M. 2004. Genotype and phenotype associations with drought tolerance in barley tested in North Africa, Annals of Applied Biology. 144: 157- 168. 
Galal, T.M. 2001. Studies on the River Nile Vegetation in El Kahira El Kobra. MSc. Thesis, Faculty of Science, Helwan University, Cairo, Egypt. 187 pp.

Galal, T.M. 2005. Flora and vegetation of north lakes of Egypt.Ph.D.These, Helwan University, Helwan. 285 pp.

Galal, T.M. and Shehata, H.S. 2015. Impact of nutrients and heavy metals capture by weeds on the growth and production of rice (Oryza sativa L.) irrigated with different water sources. Ecological Indicators. 54: 108- 115.

Gauch, H.G. 1980. Multivariate Analysis in Community Ecology, Cambridge University. press, Cambridge. 298 pp.

Gauch, H.G. and Whittaker, R.H. 1981. Hierarchical Classification of Community Data. Journal of Ecology. 69: 135- 152.

Gomaa, N.H. 2012. Composition and diversity of weed communities in Al-Jouf province, northern Saudi Arabia. Saudi Journal of Biological Sciences. 19(3): 369- 76.

Hassan, L.M. and El.Bakry, A.A. 2003. Wild species diversity in rainfed barley in the western Mediterranean coastal area of Egypt. Botany Department, Faculty of Science, Helwan University, Cairo, Egypt.

Heneidy, S.Z. and Bidak, I.M. 1998. Diversity of wadi vegetation in Matruh region, Egypt. Journal of Union of Arab Biologists Cairo, Botany. 6B: 13- 28.

Heneidy, S.Z. and Bidak, L.M. 2001. Biodiversity of the Plant Species in Bisha, Asir Region Southwestern Saudi Arabia. Pakistan Journal of Biological Sciences. 4 (11): 13231330.

Hill, M.O. 1979a. TWINSPAN: A FORTRAN Program for Arranging Multivariate Data in an Ordered To-way Table by Classification of the Individual and Attributes. Cornell University. Ithaca, New York.

Hill, M.O. 1979b. DECORANA: AFORTRAN Program for Detrended Correspondence Analysis and Reciprocal Averaging: Cornell University. Ithaca. New York. 52 pp.

Hill, M.O. and Gauch, H.G. 1980. Detrended Correspondence Analysis, an Improved Ordination Technique. Vegetatio. 42: 47-58.

Khalafallah, A.A.; Galal,T.M.; Naim, M. and Soliman, M.A. 2016b. Floristic and
Vegetation Study on the Main Weed Communities Associated with Wheat (Triticum aestivum L.) Crop. Journal of Scientific Research. 33: 64- 82.

Khalafallah, A.A.; Said, W.M.; Mohamed, S.Y. and Al Saidi, F.M. 2016a. Diversity and Vegetation Analysis of Plant species Associated with Prickly Pear (Opuntia ficusindicaL. Mill.) in Nile Delta, Egypt. Journal of Scientific Research.33: 1- 20.

Kosinová, J. 1972. On the weed flora and vegetation in Egypt. Egyptian.Botanical Society, Year book. 2: 1- 6.

Kosinova, J. 1975. Studies on the weed flora of cultivated land in Egypt.Preslia, 47: 58- 74.

Magurran, A.E. 1988. Ecological Diversity and its Measurements.Croom.Helm., London. 179 pp.

Marshall, E.J.P. 1989. Distribution patterns of plants associated with arable field edges. Journal of Applied Ecology.26: 247- 257.

Meigs, P. 1973. World distribution of coastal deserts, their natural and human environments.David, H.K., Amiran and Andrew, W.W. (Eds.), University of Arizona Press. 3- 13 pp.

Muller-Dombois, D. and Ellenberg, H. 1974. Aims and Methods of Vegetation Ecology.John Wiley and Sons, New York.

Naylor, R.E.L. 2002. Weed management handbook. $9^{\text {th }}$ eds. British Crop Protection Enterprise, Blackwell Science, Ltd.

Nevo, E. 1992. Origin, evolution, population genetics and resources for breeding of wild barley, Hordeum spontaneum, in the fertile crescent. Chapter 2. In: PR Shewry, ed. Barley: Genetics, Biochemistry, Molecular Biology and Biotechnology. C.A.B International, Wallingford, Oxon. 19- 43 pp.

OECD. 2004. Consensus document on compositional considerations for new varieties of barley (Hordeum vulgare L.): Key food and feed nutrients and anti-nutrients. Report No. 12, Environment Directorate, OECD, Paris.

Palmer, M.W. and Maurer, T.A. 1997. Does diversity beget diversity? A case study of crops and weeds. Journal of Vegetation Science.8: 235- 240.

Pielou, E.C. 1975. Ecological Diversity. A Willy-Interscience Publication New York, 165 pp. 


\section{Phytosociology of rainfed barely along the western Mediterranean Coast}

Raunkiaer, C. 1973. Plant Life Forms. Clarendon, Oxford. 104 pp.

Raven, P. 1971. Relationships between Mediterranean floras. In: PH Davis, PC Harper \& IC Hedge (Eds.) Plant Life in South West Asia. Botanical Society of Edinburgh, Edinburgh. 119- 134.

Sans, F.X. and Masalles, R.M. 1995. Phenological patterns in an arable land weed community related to disturbance. Weed Research. 35: 321- 332.

Shaltout, K.H. 1985. On the diversity of the vegetation in western Mediterranean coastal region of Egypt. Proc. Egypt, Botanical Society. 4: 1355- 1376.

Shaltout, K.H.; Ahmed, D.A. and Shabana, H.A. 2015. Distribution of the associated species with Phlomis aurea Decne along an elevation gradient in Southern Sinai, Egypt. Ecologia Mediterranea. 42(1): 65- 77.

Shehata, H.S. and Galal, T.M. 2014. Phytosociology and phytochemical screening of the medicinal weed Malva parviflora L. Life Sciences Journal, 11(6): 458- 468.

Spink, A.J. 1992. The Ecological Strategies of Aquatic Ranunculus Species.Ph.D.Thesis, Glasgow University. Glasgow.

Tadros, T.M. and Atta, B.A.M. 1958. The plant communities of barley fields and uncultivated desert areas of Mareotis (Egypt). Vegetatio 8: 161- 175.

Täckholm, V. 1974. Students Flora of Egypt. $2{ }^{\text {nd }} E d n$., Cairo University Press, Egypt. (publ.), Cooperative Printing Company, Beirut, 888 pp.
UNESCO, 1977. Map of the world Distribution of arid regions. MAB Technical Notes. 7.

Von Bothmer, R. 1992. The wild species of Hordeum: Relationships and potential use for improvement of cultivated barley. In: Swewry PR, editor. Barley: Genetics, Biochemistry, Molecular Biology and Biotechnology. Willingford, Oxon: The Centre for Agriculture and Bioscience International. 3- 18 pp.

Whittaker, G.H. 1972. Evolution and Measurement of Species Diversity.Taxon.21: 231- 251.

Zahran, M.A. and Willis, A.J. 1992. The Vegetation of Egypt.Chapman\& Hall, London. $424 \mathrm{pp}$.

Zahran, M.A. and Willis, A.J. 2009. The Vegetation of Egypt. $2^{\text {nd }}$ ed. Springer, Dordrecht, Netherlands.

Zhao, D.L.; Atlin, G.N.; Bastiaans, L. and Spiertz, J.H.J. 2006. Developing selection protocols for weed competitiveness in aerobic rice.Field Crops Research. 97: 272- 285.

Zhou, M.X. 2010. Barley production and consumption. In: Genetics and Improvement of Barley Malt Quality, G. Zhang and C. Li, eds. Springer, Berlin, Germany, 1-17pp.

Zimdahl, R.L. 2007. Fundamental of weed science.Academic Press, Burlington, Massachusetts.

Zohary, M. 1966. Flora Palaestina. Vol. 1, The Israel Academy of Sciences and Humanities, Jerusalem. 364 pp.

Zohary, M. 1972. Flora Palaestina. Vol. 2, The Israel Academy of Sciences and Humanities, Jerusalem. 489 pp. 